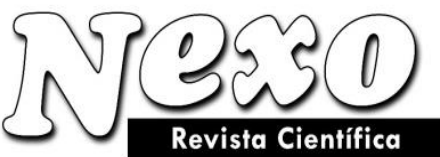

\title{
Changes in physical and mechanical properties of soils due to anthropogenic impact on the territory of Chita
}

\section{Cambios en las características físicas y mecánicas de los suelos a causa del impacto antropogénico en el territorio de Chita}

\author{
Danil D. Shesternev \\ Melnikov Permafrost Institute Siberian Branch, Russian Academy of Sciences. Yakutsk, Russia. \\ *shdd@inbox.ru
}

(recibido/received: 15-mayo-2021; aceptado/accepted:05-junio-2021)

\begin{abstract}
When constructing buildings and engineering structures it is necessary to make a pit for the foundation construction. Excavation works, construction of buildings and engineering structures change the deformation-strength properties of soils, which lie under the foundations. To study the changes in engineering-geological conditions during 2016-2018, on one of the construction sites in Chita (Russia), a well was made to take a soil sample and laboratory studies on physical and mechanical properties of soils were performed. As a result of the studies, it was established that the deterioration of the soils' deformation characteristics under the foundations increased by 2.5 times, from $20 \mathrm{MPa}$ to $8 \mathrm{MPa}$. The strength characteristics changed almost by 2 times. The soil's specific cohesion changed from $31 \mathrm{MPa}$ to $16 \mathrm{MPa}$ due to freezing and thawing of the soil on the excavation face of the pit with its subsequent soaking. It is necessary to carry out additional activities to strengthen and stabilize the foundations.
\end{abstract}

Keywords: Soils; Physical and mechanical properties; Foundation pit; Anthropogenic impact; Soil soaking; Soil freezing.

\section{RESUMEN}

A la hora de construir los edificios e instalaciones de ingeniería es necesario hacer un pozo de cimentación para los cimientos. Los trabajos de excavación y la construcción de edificios e instalaciones de ingeniería provocan un cambio en las propiedades de deformación y resistencia de los suelos que se encuentran en la base de los cimientos. Para el estudio de los cambios en las condiciones geotécnicas en 2016-2018 en uno de los lugares de construcción en Chita, Rusia se llevó a cabo lo siguiente: la perforación de pozos con muestreo; estudios de laboratorio de las propiedades físicas y mecánicas de los suelos. Como resultado de estos estudios, se determinó que las características de deformación de los suelos que se encuentran en la base de los cimientos se deterioraron en 2,5 veces de los $20 \mathrm{MPa}$ a los $8 \mathrm{MPa}$, las características de resistencia cambiaron casi el doble, la cohesión específica pasó de $31 \mathrm{kPa}$ a $16 \mathrm{kPa}$, asimismo hubo inundación de los suelos de base. El cambio en el estado de tensión-deformación de los suelos está asociado con la congelación y descongelación de los suelos en el fondo del pozo con su posterior remojo. Para estabilizar los suelos de base, se deben tomar medidas adicionales para fortalecerlos.

Palabras clave: Suelos; Propiedades físicas y mecánicas; Elemento geológico y de ingeniería, Impacto antropogénico; Remojo del suelo; Zona contráctil. 


\section{INTRODUCTION}

Currently, different types of foundations are used for construction and engineering structures. Before laying the foundations, it is necessary to perform the overburden works, which help to install the designed structure of the foundation on the sufficient depth and on the soil, on which the foundation should stand. One of the types of earthworks for the installation of foundations is the pit excavation. The pit is excavated at a defined area of the ground surface, which is assigned to the construction of a specific building or engineering structure. As a result of earthworks, there is a change in the straineddeformation characteristics of the soil, leading to the engineering-geological conditions changing at the given territory. Improper performance of design and earthworks can lead to changes in engineering-geological conditions, provoking deformations of buildings and engineering structures.

According to E.M. Sergeev (1979) the geological environment is understood as "the upper part of the lithosphere, which is considered as a multicomponent dynamic system, influenced by human engineering and economic activities. The geological environment determines such activities in a certain way". Geological environment is a system that changes over time, but the scale of these changes does not happen quickly, but gradually and for a long time.

In order to change the geological environment and its engineering-geological conditions, it should be influenced by anthropogenic factors. In nature, with the absence of the human engineering and economic activity, the change of components in the geological environment occurs, as a rule, quite slowly. The geological environment reacts more rapidly and sharply on the anthropogenic impact, as its emergence is much faster than the change of natural factors. Even if the anthropogenic impact occurs on a small area, it can have a great impact on the surrounding territories in the future (Bondarik and Yerusalimskaya, 2009; Korolev, 2007; Kronik, 2016, 2017; Trofimov, 2011; Shesternev and Vasyutich, 2011).

The study of changes in engineering-geological conditions, strained and deformed soil conditions, monitoring and forecasting in the construction of various structures is an actual issue in connection with all aspects of large-scale urbanization. Various authors study this question from different points of view and use different research methods. So, for example An. J. and Sun. C., (2020) make an estimate of the impact made by the excavation at the Hefei metro station on the nearby buildings (An. and Sun., 2020). Bray J.D. (2017) raises the issue of soil liquefaction on shallow construction sites in New Zealand during seismic impact on the territory. Tang Y. (2016) raises the question of the interaction between soil and pile foundations on the basis of vertical displacements of the wall, discussing the deformation characteristics as well (Tang and Zhao, 2016). Zhang Q. (2020) examines the displacement of fencing structures around the excavated pit in time, in Anyang (China). Zhu D. (2014) analyzed the change of the soil subsidence, the displacement of piles and the mass of soil behind the piles, based on the deformation measurements. Attention was also paid to geotechnical monitoring in the construction of engineering structures (Zhu, Qin, Lin and Tian, 2014). Ahmad S. (2015) and Gryaznova E. (2018), Kuzina E. (2018) raised questions about the need for monitoring, as one of the key moments to ensure the reliability of construction and operation of engineering. The use of monitoring helps to detect and avoid irreversible procedures that occur in the system "soilfoundation-construction" and prevent deformation of buildings. Leonid N. (2017), Nikiforova, N. (2021) studied the ways to predict the deformations and strained state of the soil foundations. Li D. (2015) analyzed the database of 30 pits in Nanjing (China) and made a comparison with similar works in the world. The results of this study may also be used to predict deformations and design protective measures.

But there is no single point of view on this issue, because different buildings and engineering structures are built in different natural conditions, using the materials and principles of construction available in a particular region.

This work reveals how the excavation of the pit and the construction of the building change the engineering-geological conditions of the territory. A site in the territory of Chita (Russia) was used for 
this study. This region has soils with negative temperatures, with the inclusions of ice. These soils are unevenly distributed over the surface and in depth. At the present time, we notice only the degradation of these soils, but there are also some cases of aggradation.

Intensive construction of various buildings and engineering structures on the territory of Chita began in the second half of the $\mathrm{XX}^{\text {th }}$ century. The construction of engineering structures was carried out according to principle I (with the preservation of the frozen soils in the foundation of the building), or according to principle II (with melting of soils before construction of the building or while the building is in service), as the average annual air temperature at that time was $-3.1{ }^{\circ} \mathrm{C}$. At the present time, the rise in air temperature has led to the degradation of perennial icy soils in some parts of the city, which has led to the change of engineering-geological conditions. The urbanization in Chita made an additional impact on the geological environment.

All of the impacts mentioned above have led to changes in the conditions of the territory, so that some of the engineering structures are in a limited usage or in an emergency condition (Babelo, Mersheeva and Stetyukha, 2017; Kronik, 2017; Torgashev, Gerasimov and Stetyukha, 2007; Shesternev and Vasyutich, 2014). This article describes how the engineering-geological conditions of the territory can be changed under the influence of anthropogenic impact on the example of one of the multi-storey residential buildings on the territory of Chita. And this influence disturbed natural-anthropogenic system balance and caused the deterioration of engineering-geological conditions.

\section{MATERIALS AND METHODS}

\subsection{Characteristics of the building under construction}

On the research site, it was planned to build a ten-story residential building according to the construction principle II, that is to say using soils for construction in a melted or thawed state. The dimensions of the building were $54 \times 13.5 \mathrm{~m}$. A strip foundation was chosen with the depth of 2.1-2.8 $\mathrm{m}$ from the earth's surface. The absolute elevation of the foundation base in the Baltic system of heights was 665.40 , the height of the technical underground is $1.80 \mathrm{~m}$, the load on foundation was planned to be $700 \mathrm{kN} / \mathrm{m}$.

\subsection{The research methodology included:}

- collection, processing and analysis of archive materials with engineering surveys of previous years;

- reconnaissance survey of the construction site and the adjacent territory;

- drilling of engineering-geological wells, mining and tunneling works directly on the research site;

- laboratory studies of the physical and mechanical properties of soils;

- desk study of the received data from the site and laboratory work;

- analyzing changes in geotechnical conditions.

2.3. Collection, processing and analysis of archive materials with engineering surveys of previous years

Archive materials of various organizations that were available at JSC "ZabaikalTISIZ" and other sources were used for the analysis of engineering-geological, hydrogeological and geocryological conditions. Satellite images obtained from publicly available sources were used to analyze the terrain in the area of the residential building construction.

\subsection{Reconnaissance survey of the construction site and adjacent territory}

Engineering and geological reconnaissance was carried out with the aim of visual inspection of the existing building, identifying deformations and establishing dangerous geological processes that affect its stability, also identifying changes in the engineering and geological conditions of the built-up area. The view of the research site before the construction onset is shown in Figures 1 and 2. 


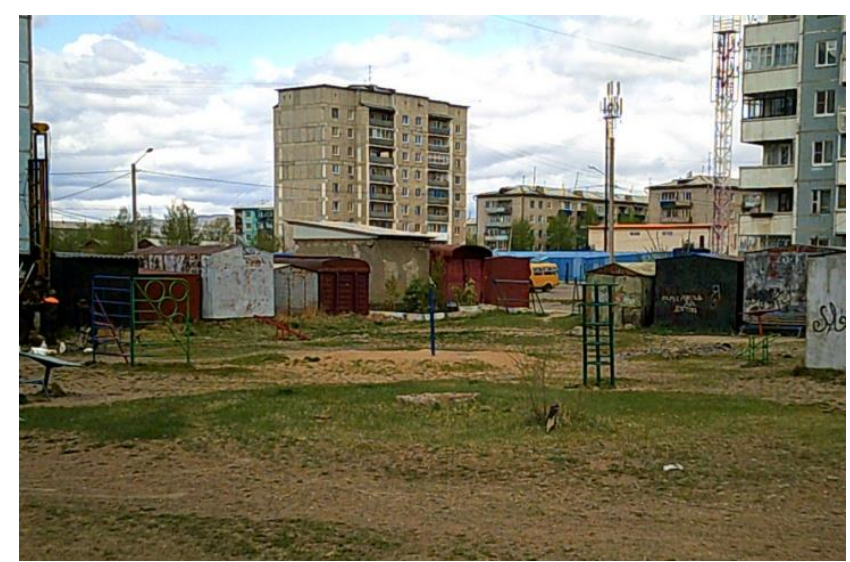

Figure 1. Construction site view before the construction onset (West)

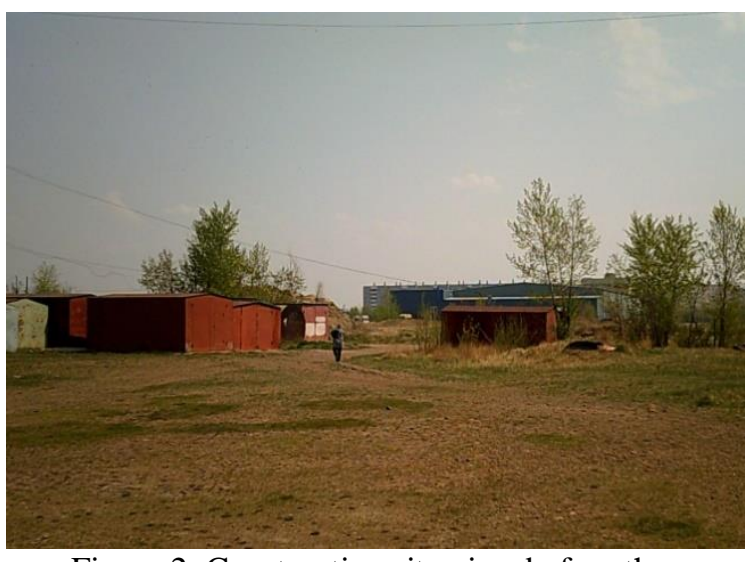

Figure 2. Construction site view before the construction onset (East)

2.5. Drilling of engineering-geological wells, mining and tunneling works directly on the research site

Drilling works were carried out to study the geological structure, hydrogeological and geocryological conditions of the site, the physical and mechanical properties of the soils for the foundation.

The wells were drilled using the core method in a dry way, with the self-propelled drilling rig of UGB$1 \mathrm{VS}, \mathrm{PBU}-1$ types (Russia). The core drilling method is rotary drilling, in which the destruction of the soil occurs along the ring, while the inner part of the soil is preserved in the form of a core. The drilling diameter was $151-133 \mathrm{~mm}$. To establish the most accurate position of the lithological boundaries in depth, the drill string penetration in one advancement was no more than $30 \mathrm{~cm}$.

In the process of drilling the engineering-geological wells, a detailed description of the core was made, the distribution boundaries of the lithological-genetic soil differences were fixed, and soil samples were taken for laboratory studies. We carried out the selection of samples from the undisturbed structure to determine the physical properties of soils in laboratory conditions from each well and from each soil difference, on average, every 1.5-2.0 lin $\mathrm{m}$ of soil. In separate intervals, sampling of soil monoliths was carried out for the subsequent determination of the deformation and strength properties of soils. When groundwater was opened, the levels of their appearance and establishment were recorded and then the water samples were taken for chemical composition and determining the aggressive properties for concrete.

Directly at the research site in 2016, 3 wells with a depth of $18 \mathrm{~m}$ were drilled at the construction site for a residential building. Drilling of engineering-geological wells was carried out to a depth equal to the building's area of influence on the foundation soils. These wells were drilled prior to construction. After the construction of the building in 2017, 3 wells with a depth from 5 to $8 \mathrm{~m}$ were drilled in close proximity to the constructed building (Figure 3). In 2018, 8 wells with a depth of 6 m were drilled along the perimeter of the building. Drilling locations for engineering-geological wells are shown in Figure 4. 


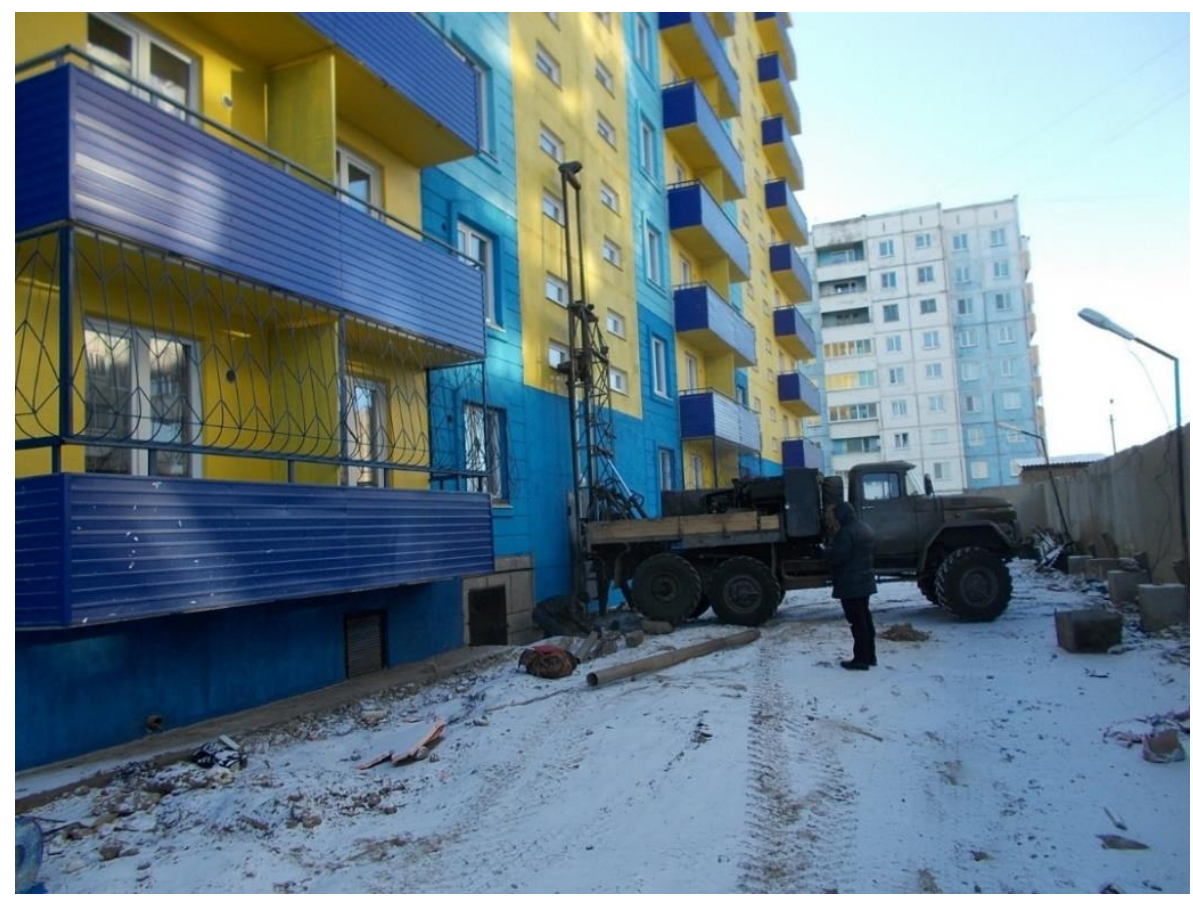

Figure 3. Drilling an engineering-geological well in 2017

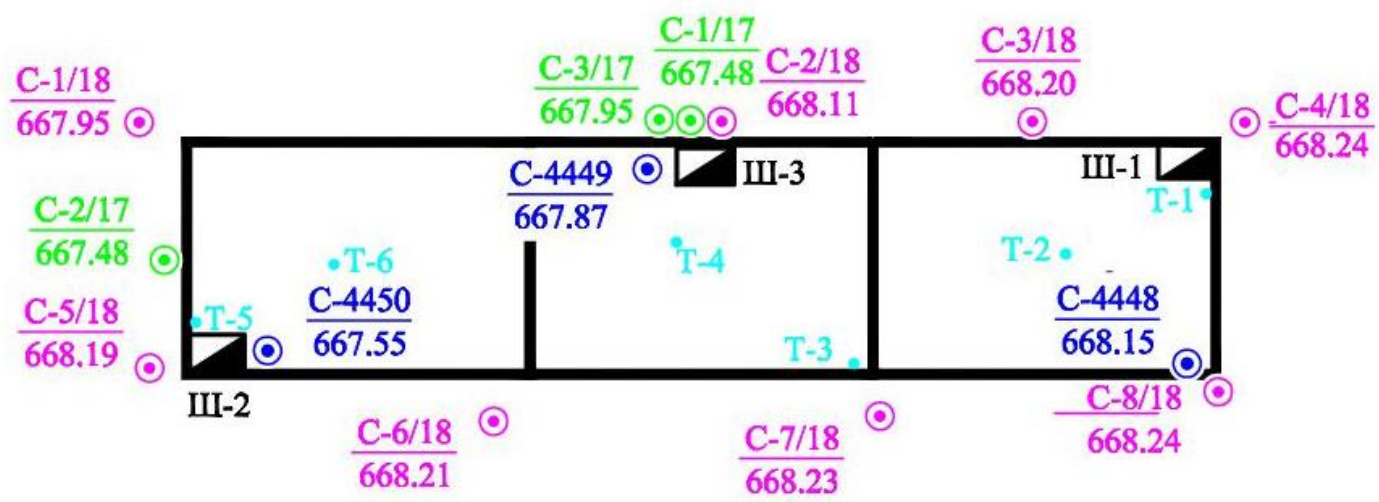

Legend:

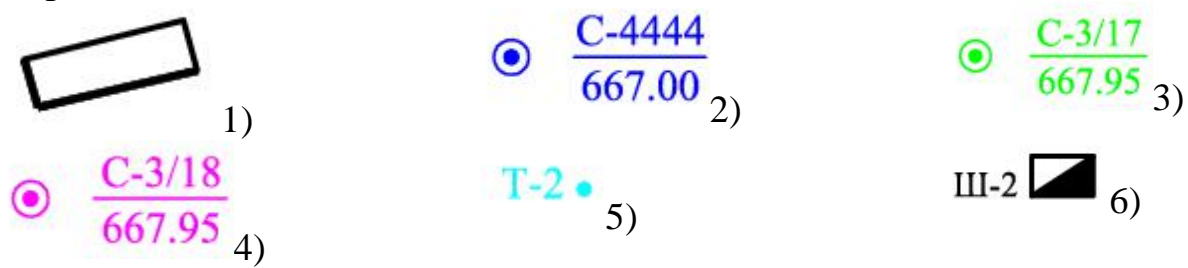

1) Building contours; 2) Wells drilled in 2016; 3) Wells drilled in 2017; 4) Wells drilled in 2018; 5) Drilling points in the basement of the building; 6) Pits in the basement of the building

Figure 4. Layout of geotechnical works

To determine the physical characteristics of the soils' properties directly under the base of the foundation, it was planned to drill pits in the basement of the building: pit No. 1 in the area of the well No. 4/18, pit No. 2 in the area of the well No. 5/18, pit No. 3 in the area of the well No. 2/18. Inside the basement of the building, 6 wells were drilled using a portable small-sized drilling rig to clarify the roof of the foundation's concrete pad. 


\subsection{Laboratory research of the soils' physical and mechanical properties}

After drilling and mining operations, soil samples were delivered to the soil laboratory to determine their physical and mechanical properties. A complex of physical properties of the soil was made from each soil difference, which included the following definitions: natural moisture, density at natural moisture, density of the mineral part, moisture at the rolling boundary, moisture at the fluidity boundary, and granulometric composition. Samples were taken from separate intervals to determine the deformation and strength characteristics of the soil, like modulus deformation, specific adhesion, angle of internal friction. A total of 27 samples were taken for laboratory determination of soil properties (27 samples in 2016, 14 samples in 2017, 24 samples in 2018). The mechanical properties of soils were determined with the compression and single-plane cut methods. The values of the deformation characteristics were determined in the load intervals from 0.3 to $0.4 \mathrm{MPa}$.

The determination of the physical and mechanical properties of soils was carried out in accordance with the regulatory and technical documents of the Russian Federation.

\section{RESULTS}

Administratively, the research site was located in the northwestern part of Chita in the Chernovsky administrative district. Geomorphologically, the research site is located within the erosionaccumulative terrace of the Ingoda and Chita (rivers) valleys (Portnova, 1976). The area of works is located within the Chitino-Ingodinskaya cavity.

At the time of the geotechnical work in 2016, the site was flat, free of buildings, the absolute surface elevations varied from 667.80 to $668.05 \mathrm{~m}$ according to the Baltic system of heights.

The geological structure of the site was composed from Quaternary deposits of technogenic (tQ), alluvial (aQ) and eluvial (eQ) genesis (Figure 5). Red outline shows the border of the future foundation pit in Figure 5. The technogenic deposits were deposited to a depth of $0.7 \mathrm{~m}$ from the surface. The alluvial deposits were located in the upper part of the section, under the technogenic deposits. Alluvial deposits were represented by cohesive dispersed soils, loams of refractory and softplastic consistency. Eluvial deposits were represented by the products of weathered terrigenoussedimentary formations of the Lower Cretaceous age. They originated from siltstones and sandstones (K1) weathered to the state of finely dispersed soils (the siltstones were destroyed to the state of loam and sandy loam, sandstone was destroyed to the state of the medium-sized sand (dispersed zone of the weathered crust). There were interlayers of weakly weathered sandstones of medium strength. The thickness of sandstone interlayers varied from $0.10-15 \mathrm{~m}$ to $1 \mathrm{~m}$. From geocryological view, the soils were in a thawed state to a depth of $18.0 \mathrm{~m}$ from the surface. The upper zone of the weathering crust is more weathered $(2.0-3.0 \mathrm{~m})$ than soils that were deeper. 


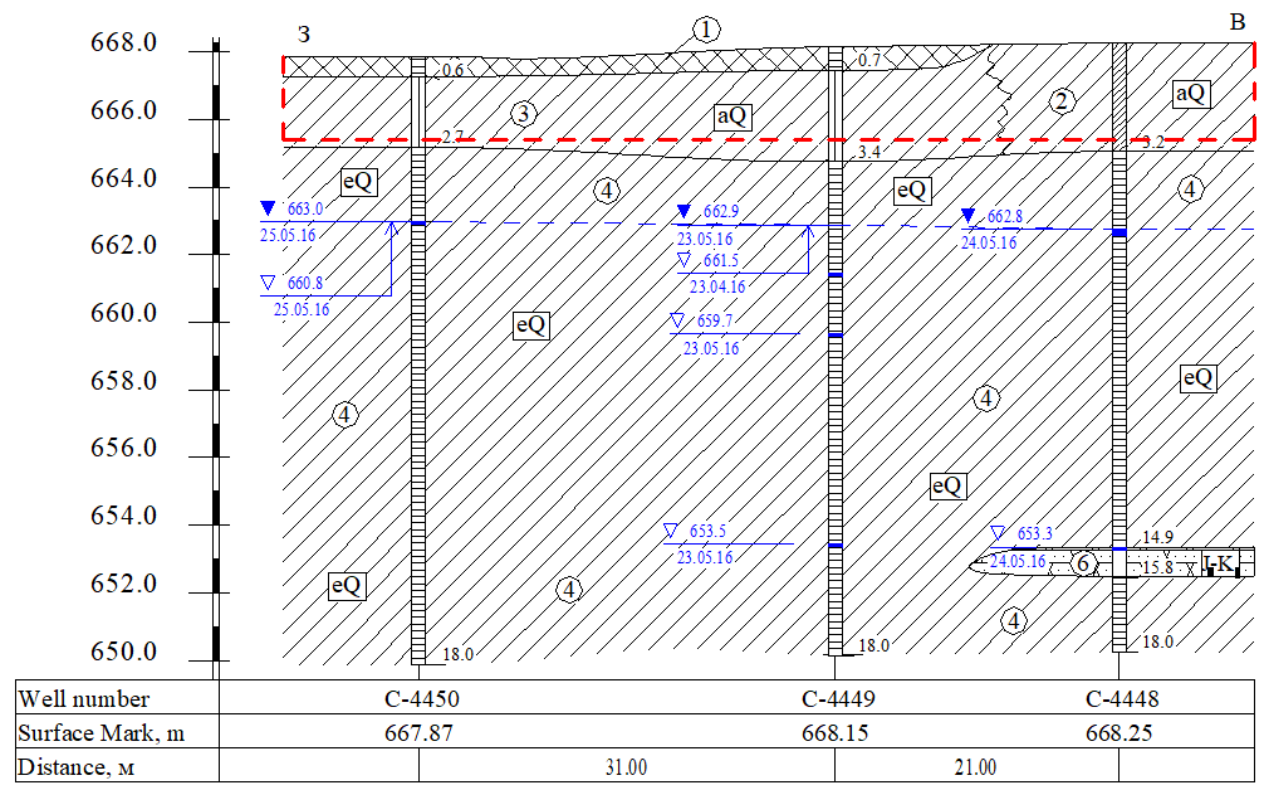

Legend:

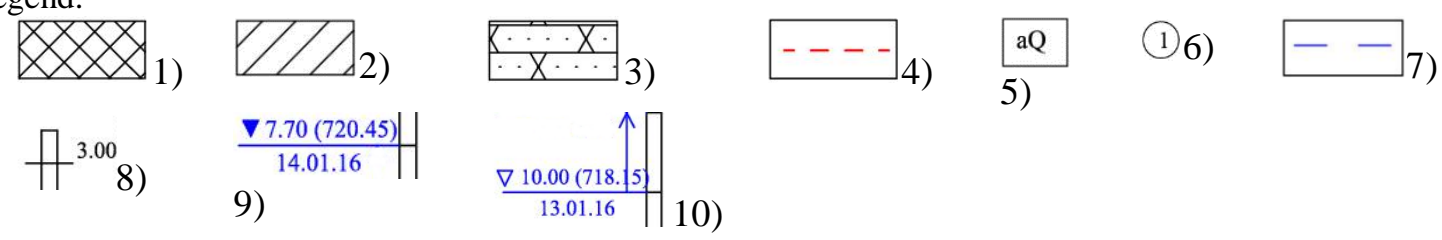

1) Filled soils; 2) loam; 3) rocky soil; 4) the contour of the pit for the building; 5) soils genesis; 6) the number of the engineering and lithological element; 7) groundwater level; 8) well in the profile cut, on the right is the depth of the layer's bottom; 9) the level of the groundwater establishment; 10) the level of the groundwater appearance

Figure 5. Engineering-geological cut of the site before the construction onset (2016)

The hydrogeological conditions of the research site were characterized by the spread of groundwater from eluvial fissure-type deposits. Groundwater was opened in all drilled wells. The waters had a head that ranged from 1.4 to $2.2 \mathrm{~m}$. In 2016, 4 engineering and geological elements were identified, thanks to laboratory research and desk study of the materials from the site.

The average values of the physical and mechanical properties of the selected engineering and geological elements are shown in Table 1.

Table 1. Identified engineering and geological elements and average values of their physical and mechanical properties for 2016

\begin{tabular}{|l|l|l|l|l|}
\hline Value (name and units) & \multicolumn{4}{l|}{ Quantitative characteristics of the soil } \\
\hline 1 & 2 & 3 & 4 & 5 \\
\hline Soil genesis & $\mathrm{tQ}$ & $\mathrm{aQ}$ & $\mathrm{aQ}$ & $\mathrm{eQ}$ \\
\hline $\begin{array}{l}\text { Engineering-geological element } \\
\text { number (EGE) }\end{array}$ & 1 & 2 & 3 & 4 \\
\hline Natural moisture $(\mathrm{W}$, dynamic units) & 0.062 & 0.257 & 0.187 & 0.161 \\
\hline Fluidity indicator $\left(\mathrm{I}_{\mathrm{L}}\right.$, dynamic units) & $<0$ & 0.60 & 0.31 & $<0$ \\
\hline Density at natural moisture $\left(\rho, \mathrm{g} / \mathrm{cm}^{3}\right)$ & 2.02 & 1.92 & 2.00 & 2.02 \\
\hline Density of dry soil $\left(\rho_{\mathrm{d}}, \mathrm{g} / \mathrm{cm}^{3}\right)$ & 1.90 & 1.53 & 1.72 & 1.75 \\
\hline Porosity coefficient $(\mathrm{e}$, dynamic units) & 0.410 & 0.734 & 0.563 & 0.660 \\
\hline Deformation modulus $(\mathrm{E}, \mathrm{MPa})$ & & 12 & 20 & 17 \\
\hline Specific adhesion $(\mathrm{c}, \mathrm{KPa})$ & & 20 & 31 & 40 \\
\hline Internal friction angle $\left(\varphi,{ }^{\circ}\right)$ & & 18 & 21 & 21 \\
\hline
\end{tabular}


Note: Numbers of engineering and geological elements: 1 - filled soils; 2 - soft-plastic loam; 3 - hardplastic loam; 4 - hard loam (eluvium of siltstones)

In the period from 2016 to 2017 (autumn), an anthropogenic impact was exerted on the engineeringgeological environment at the research site. The anthropogenic impact included the excavation of the pit for the foundation (autumn 2016) with the depth from 2.1 to $2.8 \mathrm{~m}$, installation of foundation (spring 2017), backfilling of the foundation's pockets and the installation of the residential floors of the building (summer-autumn 2017). In August 2017, the pit was soaked and water accumulated in it due to heavy rainfall, which led to deformations of the building under construction.

In the fall of 2017, additional geotechnical work was carried out, which included the drilling of geotechnical wells, laboratory studies of soil properties and desk study of the obtained data.

The performed engineering-geological studies showed that there were changes in the engineeringgeological conditions at the construction site of a residential building due to technogenic impact. The technogenic impact on the geological environment in this area was expressed in the freezing and soaking of the base soils. Frozen soils appeared as a result of the excavation works for foundation pit during the period of negative temperatures (late autumn 2016 - early winter 2017). As a result, the freezing of soils began at the bottom of the pit and this state continued until the end of winter (February 2017), forming the frozen soils of the "permanent snow patch" type (Figure 6). The thickness of such "patches" was up to $2.0 \mathrm{~m}$ (at the time of drilling, October 2017 (Figure 7). During the construction of strip foundations, the technology of backfilling of the pockets between the foundation and the pit walls was violated. As a result, pores were formed in the backfill of the pockets, resulting in the formation of a water-bearing formation of "top water" type in the technogenic deposits. Which, in turn, led not only to the soaking of the base soils, but also to an increase in the thickness of the soils, subjected to soaking, as the construction site was near to rapidly soaking soils. Due to this influence, some of the soils attributed to engineering-geological element 3 - EGE-3 (refractory loam), which lay next to the bottom of the excavated pit, changed their physical and mechanical characteristics, and, accordingly, they could already be attributed to soils EGE-2 (softplastic loam). In general, there was a deterioration in the physical and mechanical characteristics of soils in the compressible zone under the structure towards an increase of the compressibility and deformation modulus, reduction of adhesion and angle of internal friction. This is proved by an increase in the natural moisture of soils, fluidity indicator, coefficient of porosity and a decrease in density at natural moisture. In addition, due the accumulation of water from precipitations and technogenic water leaks, a "top water" was formed. At the same time, due to the freezing of the base soils, the hard loam (EGE-4) changed its state from thawed to frozen, which further enhanced its antiphilter properties.

The changed engineering-geological section of soils is shown in Figure 6, and the changed physical and mechanical properties are shown in Table 2. In Figure 6, the red line shows the contour of the foundation pit, and the violet color shows frozen soils of a "permanent snow patch" type. 


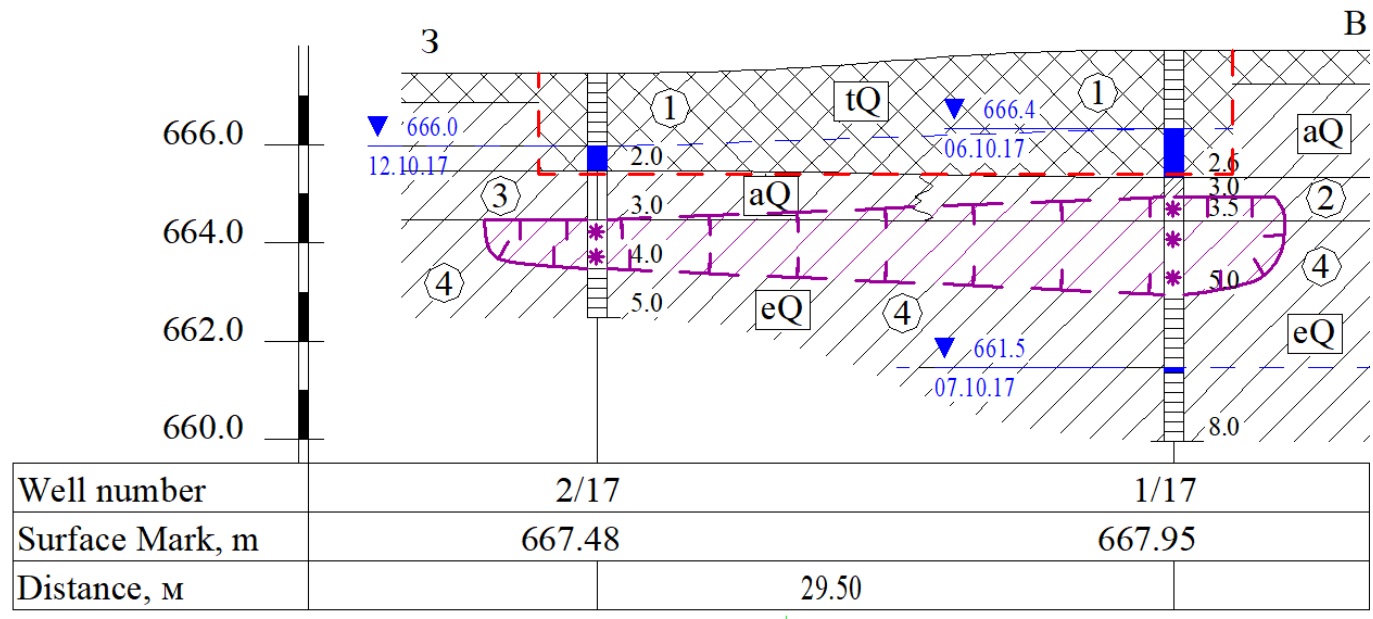

Legend:

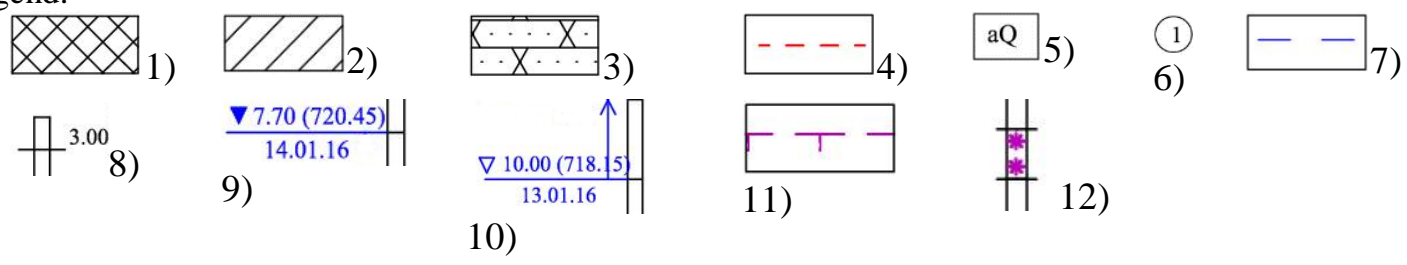

1) Filled soils; 2) loam; 3) rocky soil; 4) the contour of the pit for the building; 5) soils genesis; 6) the number of the engineering and lithological element; 7) groundwater level; 8) well in the profile cut, on the right is the depth of the layer's bottom; 9) the level of the groundwater establishment; 10) the level of the groundwater appearance; 11) the boundary of the frozen soils spreading (dash in the direction to the frozen soils spreading); 12) frozen soils

Figure 6. Engineering-geological cut (2017)

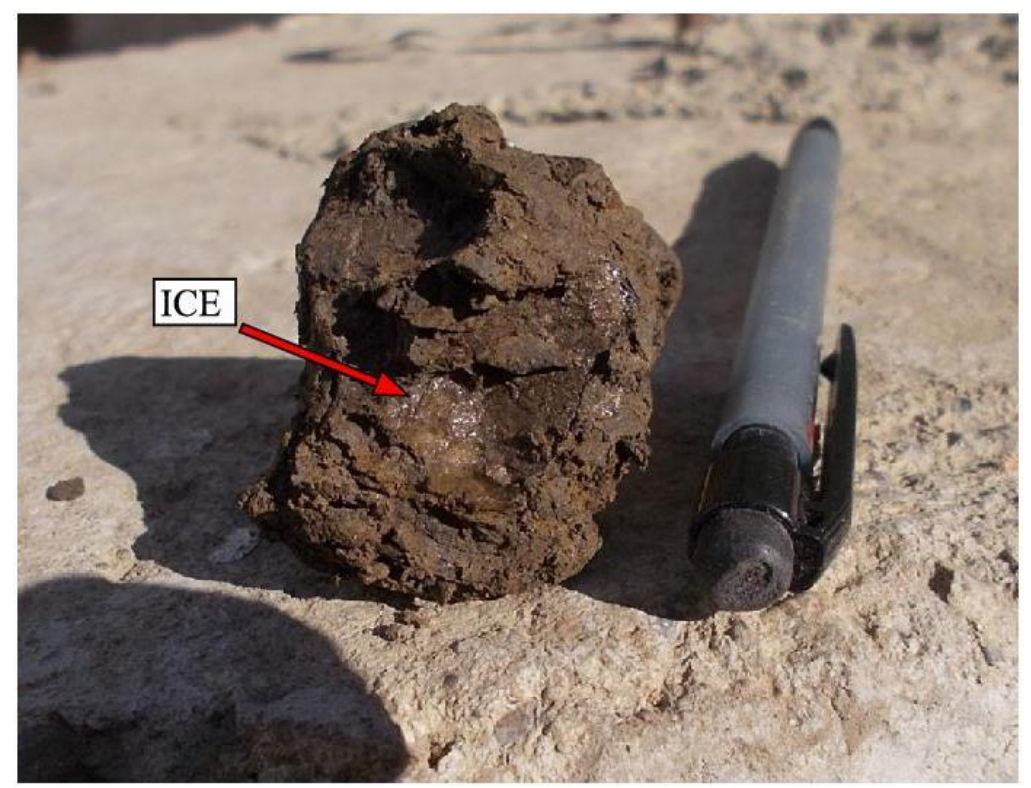

Figure 7. Frozen soils of a "permanent snow patch" type, formed after freezing of the base soils 
Table 2. Selected engineering and geological elements and average values of their physical and mechanical properties for 2017

\begin{tabular}{|l|l|l|l|l|}
\hline Value (name and units) & \multicolumn{4}{l|}{ Quantitative characteristics of the soil } \\
\hline 1 & 2 & 3 & 4 & 5 \\
\hline Soil genesis & tQ & aQ & aQ & eQ \\
\hline $\begin{array}{l}\text { Engineering-geological element number } \\
\text { (EGE) }\end{array}$ & 1 & 2 & 3 & 4 \\
\hline Natural moisture $(\mathrm{W}$, dynamic units) & 0.187 & 0.255 & 0.260 & 0.179 \\
\hline Fluidity indicator $\left(\mathrm{I}_{\mathrm{L}}\right.$, dynamic units) & 0.77 & 0.70 & 0.48 & $<0$ \\
\hline Density at natural moisture $\left(\rho, \mathrm{g} / \mathrm{cm}^{3}\right)$ & 2.06 & 1.91 & 1.95 & 1.98 \\
\hline Density of dry soil $\left(\rho_{\mathrm{d}}, \mathrm{g} / \mathrm{cm}^{3}\right)$ & 1.73 & 1.48 & 1.55 & 1.68 \\
\hline Porosity coefficient $(\mathrm{e}, \mathrm{dynamic}$ units) & 0.537 & 0.782 & 0.712 & 0.570 \\
\hline Deformation modulus $(\mathrm{E}, \mathrm{mPa})$ & & 10 & 15 & 17 \\
\hline Specific adhesion $(\mathrm{c}, \mathrm{kPa})$ & & 18 & 24 & 40 \\
\hline Internal friction angle $\left(\varphi,{ }^{\circ}\right)$ & & 17 & 21 & 21 \\
\hline
\end{tabular}

Note: Numbers of engineering-geological elements: 1 - filled soils; 2 - soft-plastic loam; 3 - hardplastic loam; 4 - hard loam (eluvium of siltstones)

In 2018, additional geotechnical works were carried out in order to obtain information on the geotechnical conditions of the research site. Additional geotechnical wells were drilled at the research site (Figure 4). Some of these wells were drilled outside the area of the excavated pit, in order to establish the invariability of natural conditions outside the territory affected by technogenic impact (Figure 8). Another part of the wells was drilled in a close proximity to the outer bearing walls of the constructed building and therefore fell into a backfilled pit in order to establish the further dynamics of the engineering-geological conditions of the research site, in the compressible zone of the structure (Figure 9). To determine the physical properties of soils directly under the foundation base, it was planned to drill three test pits in the basement of the building directed to different walls of the building. Digging of test pits at a depth of $0.5 \mathrm{~m}$ from the basement floor was stopped due to the presence of groundwater of a "top water" type. Additional wells were drilled using a portable smallsized drilling rig to clarify the elevation of the roof of the foundation's concrete pad inside the basement of the building. 


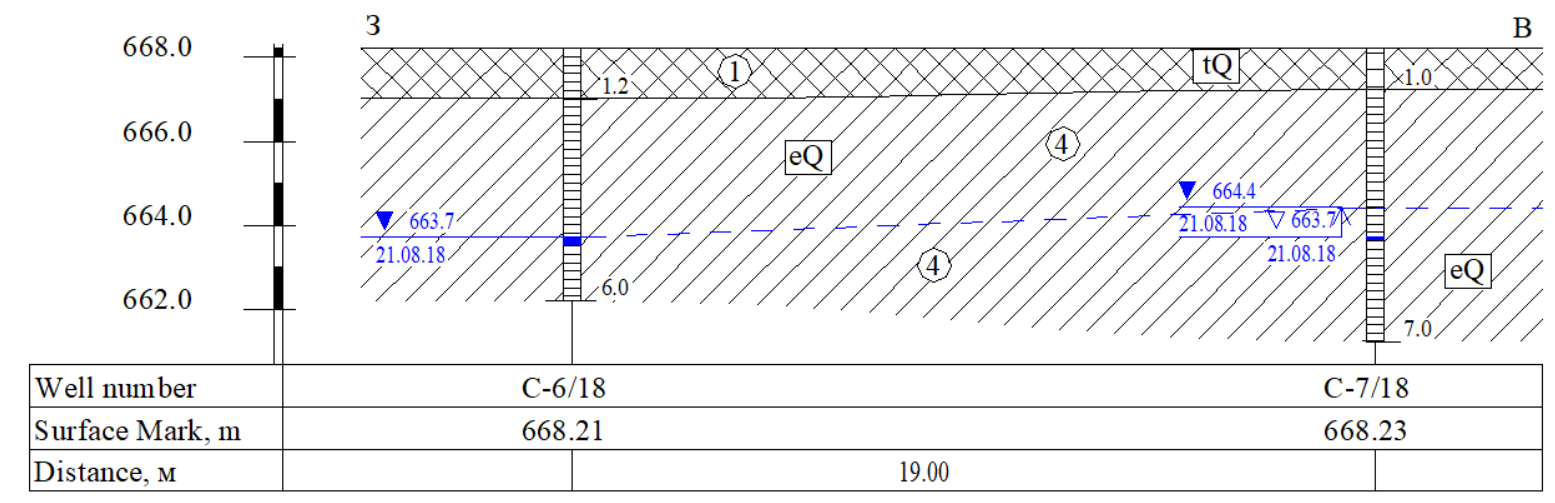

Legend:

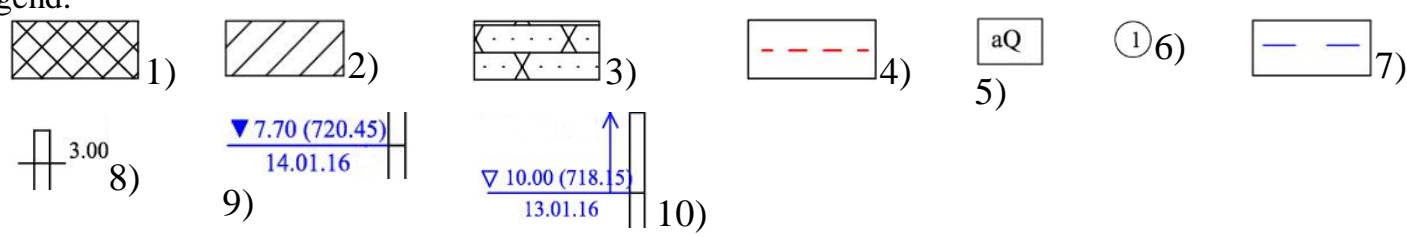

1) Filled soils; 2) loam; 3) rocky soil; 4) the contour of the pit for the building; 5) soils genesis; 6) the number of the engineering and lithological element; 7) groundwater level; 8) well in the profile cut, on the right is the depth of the layer's bottom; 9) the level of the groundwater establishment; 10) the level of the groundwater appearance

Figure 8. Engineering-geological cut of the wells located outside the pit (2018)

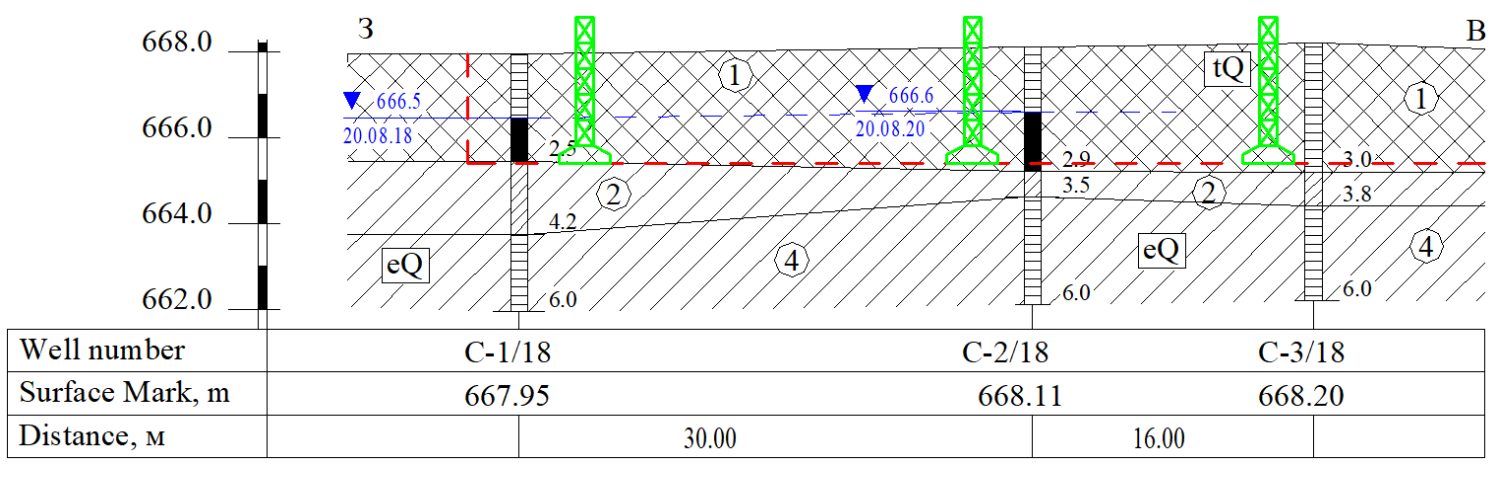

Legend:

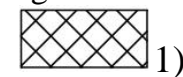

$\bigoplus^{3.00} 8$ )

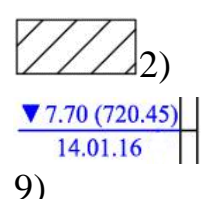

9)

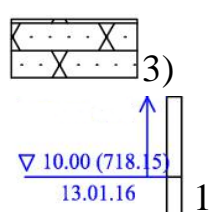

10)

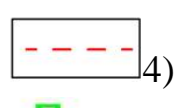

aQ 5)

(1)

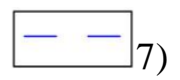<smiles>[R]C1CC1</smiles>

1) Filled soils; 2) loam; 3) rocky soil; 4) the contour of the pit for the building; 5) soils genesis; 6) the number of the engineering and lithological element; 7) groundwater level; 8) well in the profile cut, on the right is the depth of the layer's bottom; 9) the level of the groundwater establishment; 10) the level of the groundwater appearance; 11) building's foundations

Figure 9. Engineering-geological cut of the territory (2018) 


\section{DISCUSSION}

After studying the engineering and geological conditions, the following information was revealed:

4.1) the geological and lithological section for wells drilled outside the pit contour is identical to the previously performed surveys (Figure 8), this indicates a change in engineering and geological conditions only within the existing structure (pit contour);

4.2) there are no frozen soils in the drilled wells within the investigated depth of $6.0 \mathrm{~m}$, that is to say, there was a degradation of frozen soils that were previously exposed in the seasonally active layer;

4.3) digging pits at a depth of $0.5 \mathrm{~m}$ from the basement floor was stopped due to the presence of groundwater of a "top water" type;

4.4) as a result of anthropogenic impact on the geological environment, refractory loam changed its physical and mechanical characteristics and became soft-plastic loam;

4.5) two underground water levels were discovered within the site:

- the first level - water of a "top water" type, which was discovered in the filled soils inside the structure at depths of 0.3-0.5 m from the basement floor and at a depth of 1.1-1.5 m from the ground surface (according to drilled engineering-geological wells and digged pits) (Figure 9);

- the second level - waters of eluvial sediments, opened at a depth of $4.5 \mathrm{~m}$ from the ground surface, which corresponds to marks of 663.37-663.74 $\mathrm{m}$, so there was a rise in water by $1.0 \mathrm{~m}$ in comparison with previous surveys (Figure 7);

4.6) the soaking of soils at the base of the building continues, as the thickness of the soaked soils increased from $0.65 \mathrm{~m}$ to $0.90 \mathrm{~m}$ (2017) and then to $1.12 \mathrm{~m}$ (2018) (Figure 10). Consequently, the accumulation of water continues at the bottom of the pit and directly under the foundation in the compressible zone. It is also possible that there is the water inflow into the basement of the building of a technogenic kind, due to leaks from engineering networks;

4.7) the dynamics of the main physical and mechanical characteristics of soils is shown in Table 3. Based on a comparison of data from this table, it can be seen that with an increase in natural moisture, fluidity index, porosity coefficient, the density of EGE-2 soil (soft-plastic loam) decreases, which leads to decrease in the deformation and strength characteristics of the soil (Figures 10, 11). Refractory loam (EGE-3), due to soaking, became soft-plastic loam (EGE-2). Based on a comparison of the data from Table 3, it can be concluded that an increase in the porosity of alluvial loams was a consequence of the soils freezing in the foundation pit. So, an increase in the consistency index and a decrease in the deformation modulus was caused by freezing and subsequent thawing under soaking conditions. At the same time, it can be seen from this table that the characteristics of eluvial soils, which lie in the lower part of the section, remained unchanged and retained their deformation and strength properties. 
Table 3. Changes in the values of the main physical and mechanical characteristics of soils in the period from 2016 to 2018

\begin{tabular}{|l|l|l|l|}
\hline Characteristics of soils (units) & 2016 & 2017 & 2018 \\
\hline Natural moisture $($ dynamic units) & 0.187 & 0.255 & 0.299 \\
\hline Fluidity indicator $($ dynamic units) & 0.31 & 0.70 & 0.72 \\
\hline Soil density at natural moisture $\left(\mathrm{g} / \mathrm{cm}^{3}\right)$ & 2.00 & 1.91 & 1.88 \\
\hline Density of dry soil $\left(\mathrm{g} / \mathrm{cm}^{3}\right)$ & 1.72 & 1.48 & 1.45 \\
\hline Porosity coefficient $($ dynamic units) & 0.563 & 0.782 & 0.829 \\
\hline Saturation coefficient $($ dynamic units) & 0.897 & 0.970 & 0.952 \\
\hline Deformation modulus $(\mathrm{mPa})$ & 20 & 10 & 8 \\
\hline Specific adhesion $(\mathrm{c}, \mathrm{kPa})$ & 31 & 18 & 16 \\
\hline Internal friction angle $\left({ }^{\circ}\right)$ & 21 & 17 & 16 \\
\hline Natural moisture $($ dynamic units) & 0.161 & 0.179 & 0.188 \\
\hline Fluidity indicator $($ dynamic units) & $<0$ & $<0$ & $<0$ \\
\hline Soil density at natural moisture $\left(\mathrm{g} / \mathrm{cm}^{3}\right)$ & 2.02 & 1.98 & 1.98 \\
\hline Density of dry soil $\left(\mathrm{g} / \mathrm{cm}^{3}\right)$ & 1.75 & 1.68 & 1.67 \\
\hline Porosity coefficient $($ dynamic units) & 0.516 & 0.570 & 0.572 \\
\hline Saturation coefficient $($ dynamic units) & 0.820 & 0.830 & 0.861 \\
\hline Deformation modulus $(\mathrm{mPa})$ & 17 & 17 & 17 \\
\hline Specific adhesion $(\mathrm{kPa})$ & 40 & 40 & 40 \\
\hline Internal friction angle $\left({ }^{\circ}\right)$ & 21 & 21 & 21 \\
\hline
\end{tabular}

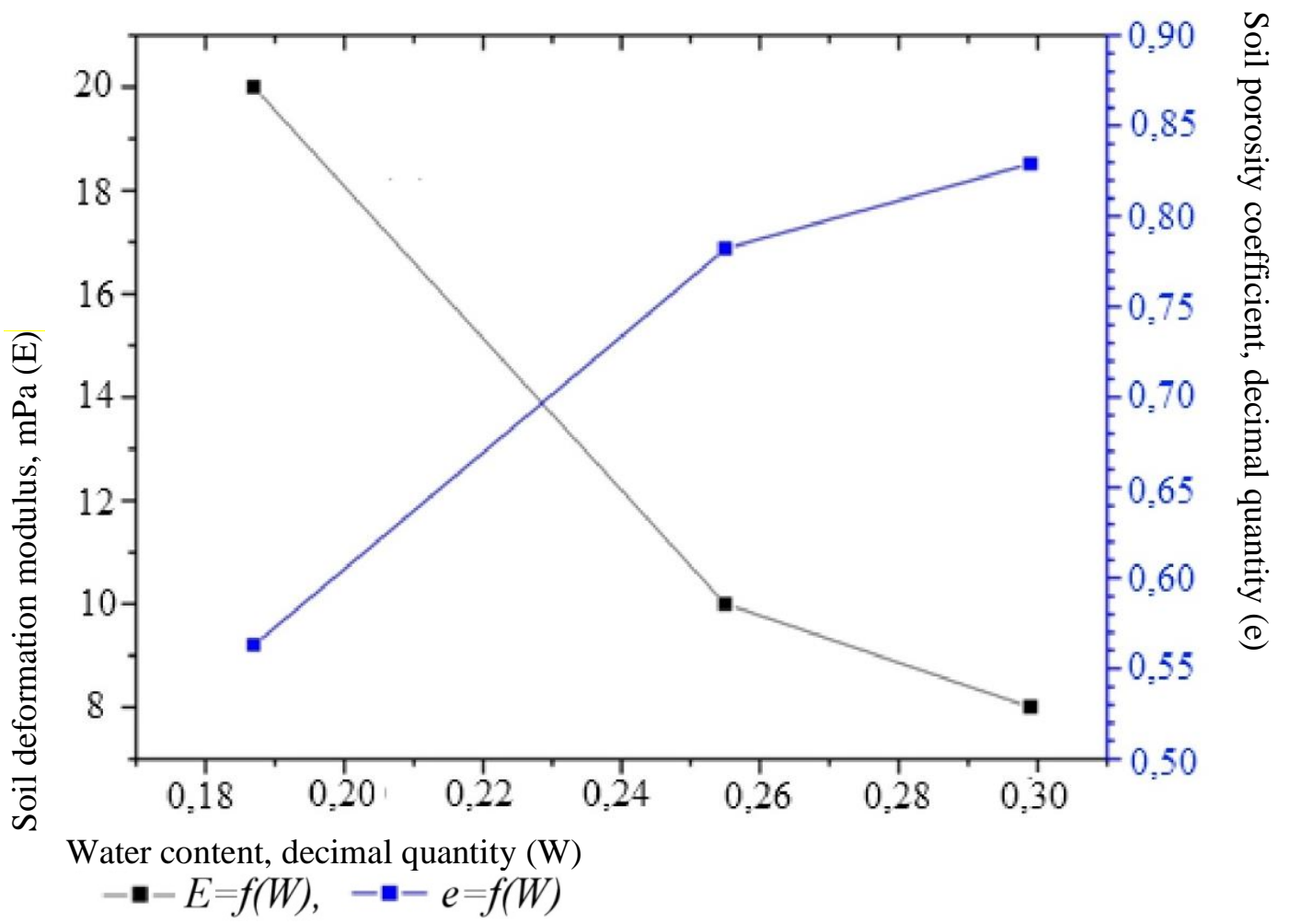

Figure 10. Graphs of changes in the deformation modulus and in the porosity coefficient at natural moisture content in alluvial loam 


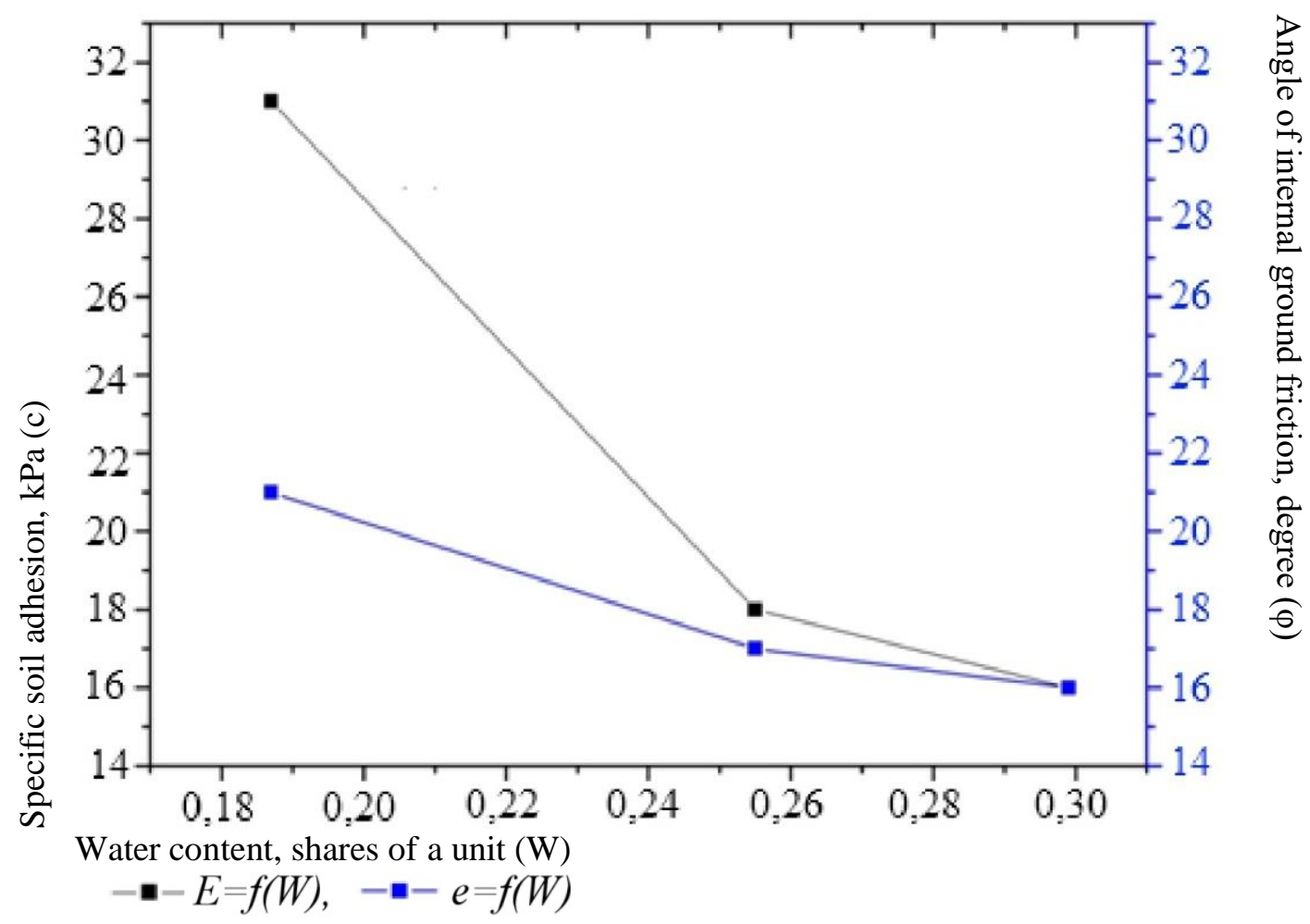

Figure 11. Graphs of changes in the adhesion and angle of internal friction at natural moisture content in alluvial loam

4.8) the work site has become a complex category of geotechnical conditions for construction. In such territories, it is necessary to carry out a set of measures to study the engineering-geological environment, and it is also necessary to apply measures to strengthen the foundation soils.

\section{CONCLUSION}

5.1. As a result of negative technogenic interference on the geological environment, there has been a significant change in the engineering and geological conditions of the construction site. The main reasons for the deterioration of the soils' properties were the freezing of the foundation pit and subsequent thawing under soaking conditions. This resulted in the decrease of the deformation and strength characteristics of soils in the compressive zone and made soils under the building unreliable for its foundation.

5.2. Highly deformable soils under the foundation of the constructed building caused uneven settlements of the soil over the area. Traces of deformations appeared on the supporting structures of the building in the form of cracks in the center of the building. We also discovered that the walls have lack of perpendicularity.

5.3. The research area changed the complexity category of engineering and geological conditions from II (medium complexity) to III (high complexity), which led not only to the need for a comprehensive additional study of the geological environment, but also to a significant increase in the cost of construction on this research site, since now it is necessary to take additional measures to stabilize the foundation soils in order to stop the deformations of the building.

5.4. Long-term monitoring of the geological environment is required to take any measures to improve the engineering and geological conditions. Comprehensive measures should be taken to stabilize the foundation soils with the involvement of specialized scientific organizations that would have highly qualified specialists in this field. 


\section{REFERENCES}

Ahmad, S., Hamparian, R., Alashkar, M., Istafanous, K., Bader, E., Morsy, R., and Marzouk, H. (2015). Implementation of a health monitoring strategy for a high-rise building structure. Proceedings, Annual Conference - Canadian Society for Civil Engineering.

An., J., and Sun., C. (2020). Safety assessment of the impacts of foundation pit construction in metro station on nearby buildings. International Journal of Safety and Security Engineering, 10 (3), 423-429.

Babelo, V.A., Mersheeva, M.B., and Stetyukha, V.A. (2017). Experience in operating buildings on permafrost soils in the Trans-Baikal Territory. ZabGU Bulletin, 23 (11), 57-67.

Bondarik, G.K., and Yarg, L.A. (2011). Engineering and geological surveys, $3^{\text {rd }}$ ed. Moscow: RGGRU.

Bondarik, G.K., and Yerusalimskaya, E.N. (2009). Scientific bases and methods of organizing a regime network for monitoring regional natural and technical systems. Proceedings of universities. Geology and exploration, 5, 56-62.

Bray, J.D., Markham, C.S., and Cubrinovski, M. (2017). Liquefaction assessments at shallow foundation building sites in the Central Business District of Christchurch, New Zealand. Soil Dynamics and Earthquake Engineering, 92, 153-164.

Gryaznova, E. (2018). Geotechnical monitoring to ensure reliability of construction and operation of buildings and structures. IOP Conference Series: Materials Science and Engineering.

Korolev, V.A. (2007). Monitoring of geological, lithotechnical and ecological-geological systems. Moscow: KDU.

Kronik, Ya.A. (2016). Analysis of accidents and safety of geotechnical systems in permafrost conditions. Proceedings of the V conference of geocryologists of Russia. Vol. 1. (pp. 104-111). Moscow.

Kronik, Ya.A. (2017). Safety of bases, foundations of buildings and structures on permafrost soils. Base, foundation and soil mechanics, 3, 36-39.

Kuzina, E., and Rimshin, V. (2018). Deformation Monitoring of Road Transport Structures and Facilities Using Engineering and Geodetic Techniques.

Leonid, N., Matvey, N., Askar, K., Zohir, K., and Kseniya, P. (2017). Investigation of the effect of the deformation anisotropy on the stress-strain state of the soil basement. ICSMGE 2017 - 19th International Conference on Soil Mechanics and Geotechnical Engineering.

Li, D., Li, Z., and Tang, D. (2015). Three-dimensional effects on deformation of deep excavations. Proceedings of the Institution of Civil Engineers: Geotechnical Engineering, 168 (6), 551-562.

Nikiforova, N.S., and Konnov, A.V. (2021). Predicting Deformations of the Surrounding Buildings Foundations with Regard to Protective Measures. Soil Mechanics and Foundation Engineering, 57 (6), 445-451.

Portnova, V.P. (1976). Engineering and geological conditions of Central and Eastern Transbaikalia. Moscow: Nedra.

Sergeev, E.M. (1979). Engineering geology - the science of the geological environment. Engineering geology, 1, 3-19. 
Shesternev, D.M., and Vasyutich, L.A. (2011). Investigation of anthropogenic influences on the change in the geological conditions of urbanized territories of the southern permafrost (on the example of Chita). ChitGU Bulletin, 6, 117-121.

Shesternev, D.M., and Vasyutich, L.A. (2014). Transformation of the geological and geocryological environment in the process of urbanization of the city of Chita. ZabGU Bulletin, 3 (106), 57-67.

Tang, Y., and Zhao, X. (2016). Field testing and analysis during top-down construction of super-tall buildings in Shanghai. KSCE Journal of Civil Engineering, 20 (2), 647-661.

Torgashev, V.V., Gerasimov, V.M., Stetyukha, V.A. (2007). Investigation of deformations in a residential building in the changed geocryological conditions of the construction site. Bulletin of ChitGU, 4 (45), 44-49.

Trofimov, V.T. (2011). Topical issues of studying soils in engineering geology and ecological geology. Geology, geography and global energy, 2 (41), 6-13.

Zhang, Q. (2020). Deformation analysis of deep foundation pit excavation in China under time-space effect. Geotechnical Research, 7 (3), 146-152.

Zhu, D., Qin, L., Lin, Y., and Tian, R. (2014). The land subsidence and building deformation during the excavation process of the deep foundation pit. Electronic Journal of Geotechnical Engineering, 19 (Z1), 9851-9864.

\section{SEMBLANCE OF THE AUTHORS}

Danil D. Shesternev: He is a Candidate of Geological and Mineralogical Sciences, Research Fellow at the Melnikov Permafrost Institute Siberian Branch of Russian Academy of Sciences. His fields of scientific interests include engineering geology, engineering permafrost, engineering geological surveys. 